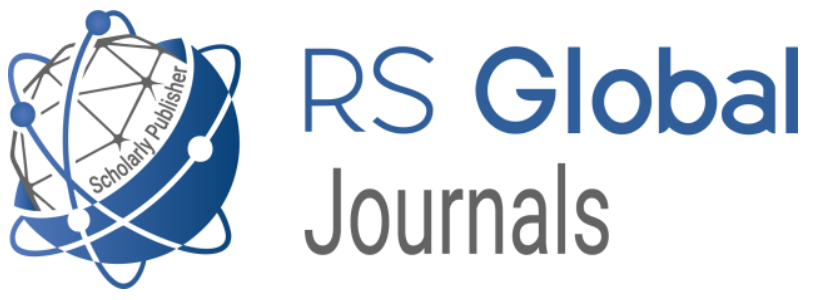

Scholarly Publisher

RS Global Sp. z O.O.

ISNI: 0000000484952390

Dolna 17, Warsaw, Poland 00-773

Tel: +48226022703

Email: editorial_office@rsglobal.pl

JOURNAL International Journal of Innovative Technologies in Social Science

p-ISSN

2544-9338

e-ISSN

2544-9435

PUBLISHER

RS Global Sp. z O.O., Poland

ARTICLE TITLE

ONLINE LEARNING STRATEGIES IN TARAS

ARTICLE THLE

SHEVCHENKO NATIONAL UNIVERSITY OF KYIV AS A POST-PANDEMIC OUTCOME

$\operatorname{AUTHOR}(\mathbf{S})$

Maryna Rebenko, Oksana Nikolenko, Natalia Doronina

Maryna Rebenko, Oksana Nikolenko, Natalia Doronina. (2021)

Online Learning Strategies in Taras Shevchenko National

ARTICLE INFO

University of Kyiv as a Post-Pandemic Outcome. International

Journal of Innovative Technologies in Social Science. 2(30). doi:

10.31435/rsglobal_ijitss/30062021/7595

DOI

https://doi.org/10.31435/rsglobal_ijitss/30062021/7595

RECEIVED

27 April 2021

ACCEPTED

07 June 2021

PUBLISHED

11 June 2021

LICENSE

This work is licensed under a Creative Commons Attribution

4.0 International License.

(C) The author(s) 2021. This publication is an open access article. 


\title{
ONLINE LEARNING STRATEGIES IN TARAS SHEVCHENKO NATIONAL UNIVERSITY OF KYIV AS A POST-PANDEMIC OUTCOME
}

\author{
Maryna Rebenko, Ph.D. in Philology, Associate Professor of the Foreign Languages Department for \\ Mathematical Faculties, Taras Shevchenko National University of Kyiv, Ukraine. \\ ORCID ID: https://orcid.org/0000-0001-8553-3559 \\ Oksana Nikolenko, Ph.D. in Philology, Associate Professor of the Foreign Languages Department \\ for Mathematical Faculties, Taras Shevchenko National University of Kyiv, Ukraine. \\ ORCID ID: https://orcid.org/0000-0002-0469-8376. \\ Natalia Doronina, Ph.D. in Historical Sciences, Assistant Professor of the Foreign Languages \\ Department for Mathematical Faculties, Taras Shevchenko National University of Kyiv, Ukraine. \\ ORCID ID: https://orcid.org/0000-0002-6834-725X.
}

DOI: https://doi.org/10.31435/rsglobal_ijitss/30062021/7595

\section{ARTICLE INFO}

Received 27 April 2021

Accepted 07 June 2021

Published 11 June 2021

\section{KEYWORDS}

online learning, post-pandemic reality, online exam, online university platform.

\begin{abstract}
The lockdown caused by the COVID-19 outbreak mainstreamed distance learning in all educational institutions worldwide and Ukraine in particular. Kyiv University's staff faced the global challenge to teach in the crisis conditions. The university closure made it clear that remote learning demanded the implementation of totally new methodologies to cover the needs of students. An online survey resulted in approaching Zoom and Google Classroom as the most preferable and efficient in providing live learning opportunities. To reach valid data of the study, qualitative and quantitative analyses of off- and online exams were applied. The majority of respondents estimated the online exam format similar to face-to-face one and the practical value of online learning following the university shutdown as beneficial. Against this background, in post-pandemic reality, Kyiv University has applied urgent management practices to alleviate the impact of the COVID-19 pandemic on both students and staff. The new platform encompasses various modes and has covered all students and the teaching staff of Kyiv University from September 1 this year. The KNU Education Online digital platform as a multifunctional school network is a fruitful university decision to work out the strategy beneficial in the long run.
\end{abstract}

Citation: Maryna Rebenko, Oksana Nikolenko, Natalia Doronina. (2021) Online Learning Strategies in Taras Shevchenko National University of Kyiv as a Post-Pandemic Outcome. International Journal of Innovative Technologies in Social Science. 2(30). doi: 10.31435/rsglobal_ijitss/30062021/7595

Copyright: (C) 2021 Maryna Rebenko, Oksana Nikolenko, Natalia Doronina. This is an open-access article distributed under the terms of the Creative Commons Attribution License (CC BY). The use, distribution or reproduction in other forums is permitted, provided the original author(s) or licensor are credited and that the original publication in this journal is cited, in accordance with accepted academic practice. No use, distribution or reproduction is permitted which does not comply with these terms.

1. Introduction. The COVID-19 pandemic challenged teaching and learning worldwide. As the Atlantis Group of former education ministers and heads of the government admitted, "the Coronavirus global pandemic represents the most significant challenge to education globally since World War 2" (Atlantis Group Report, 2020). Pandemic-induced closures forced teachers across the globe to continue their students' education providing its high quality. It is evident that the Coronavirus pandemic has transformed the old, chalk-talk teaching model to the modern one driven by technology.

In many countries, higher education has responded to COVID-19 effectively. Indian higher education institutions have used various pedagogy for innovation, development, and engagement of students (Shenoy et al., 2020). The authors claim that technology has created a revolution in the Indian 
higher education system and it is widely accepted by all due to the crisis. In the emerging and everchanging COVID-19 context, New York University Shanghai and Duke Kunshan University offer practices of successful adaptation and rapid deployment of educational technology products, like the video-conferencing platform Zoom and online course provider Coursera (Houlden \& Veletsianos, 2020). But at the same time, many institutions have to deal with different kinds of unexpected issues. The end-of-the-year examinations have been cancelled or suspended that left the students feeling uncertain about their future. Many universities do not have enough infrastructure or resources to facilitate online teaching with immediate effect (Sahu, 2020). The researcher also focuses on the fact that nevertheless, many faculty members get training to use online learning platforms some, not techno-savvy, remain unable to cope up with this adjustment.

So, since the whole education process was switched to online training mode, it affected both teachers and students socially, economically, and emotionally.

On the $12^{\text {th }}$ of March 2020, all the educational institutions in Ukraine were quarantined due to the threat of the Coronavirus outbreak (The Order of the Ministry of Health of Ukraine No. 663, 13 March 2020). Initially, it was for three weeks, until April 3, but soon it became obvious that kindergartens, schools, colleges and universities both public and private were to remain closed for the foreseeable future. In an uncertain environment, it became evident that learning had to be continued even if it could not happen in person (The Order of the Ministry of Education and Science of Ukraine No. 406, 16 March 2020). Due to the Coronavirus crisis there appeared an opportunity to rethink and reshape Ukrainian education.

Currently, the post-pandemic globalized society is forced to face a crucial shift in all fields, particularly in social and educational ones. In the wake of university shutdown following the Coronavirus pandemic, Sandu (2020) emphasized two key emerging phenomena of social space communication virtualization and virtualization of digital space, i.e. "transferring socializing interactions to virtual environments" (Sandu, 2020, p.115). The pandemic outbreak made such a drift much more realistic - while digitalization flourished, emotional contacts decreased and traditional face-to-face interaction became mediated. Nevertheless, immediate virtualization of a training process appeared to be "disturbing" (Sandu, 2020, p.129) for both teachers and students, as the first ones were made to "rethink" the traditional in-class interaction methods, while the latter ones were in turn, compelled to give feedback relevant in such an unexpectedly reshaped situation.

2. Literature review. COVID 19 has caused schools and universities to adjust rapidly all teaching programs to digital formats. Since the late 90s, the beginning of 2000 online learning has become a part of the educational process constantly evolving and getting new forms and platforms as the developments in educational technology continue to advance (Kentnor, 2015). The era of the Internet and digital media allowed it to become a part of education at all levels to accommodate learner's individual needs beyond traditional face-to-face instructions (Blaschke \& Bedenlier, 2020; Rebenko et al., 2019). The education itself has become more student-centered and individualized, although not all higher education institutions adopted this form of learning, e.g. private liberal arts schools in America (Picciano et al., 2010). For instance, the State University of New York is already trying to implement a set of comprehensive standards that could be applied in a systematic way to assess or ensure the quality of the online program administration. Those are policies and procedures that help individual campuses examine the quality of their online offerings and develop strategies to support continuous improvement (Muller et al., 2020).

Moving towards online teaching, numerous distance education investigations are being carried out to launch significant learning transformations. Liu's research (2019) on student online learning readiness (SOLR) in social, technical, and communication domains of online environment showed that students feel comfortable using computers, although there's a need for online social competency, study strategy, technical, and communication dimensions in the instructional design of online orientations. In similar research, online student attributes, time management, and technical competencies were rated high for importance compared to communication competencies. Students were confident in online learning attributes and technical competencies compared to time management and communication (Martin et al., 2020). Stark (2019) in her study of the role of motivation in both face-to-face and online learning has concluded that online students reported lower levels of motivation compared to face-toface students, though motivation variables were more strongly correlated with course performance than learning strategies, particularly for online courses. The studies at the University of North Texas 
showed that meaningful collaboration among students and teachers during online studies leads to academic success (Robinson et al., 2017). Interesting findings were presented by the group of scientists from the University of Illinois at Urbana Champaign. The reverse process from online to face-to-face teaching showed the increase of online discussion forums and chat sessions in the face-toface course. Three strategies were transferred to classroom teaching: submission of assignments via online conference system or CMS, peer review of assignments, and collaborative writing or group work using online collaboration tools such as wikis. (Scagnoli et al., 2009).

Continuous assessment in online learning is much of an interest today too. Various studies show that besides multiple summative and formative assessments, self-assessed activities in the form of non-graded assignments appear to be useful. Many of the learning strategies show significant relationships with a few assessment variables, the most relevant and interesting relationships were found with the critical thinking strategy (Arend, 2007). Moreover, the demands for assessment are even more challenging in online environments than in face-to-face, because, without consistent, timely and relevant feedback, online students interpret their classroom experience as impersonal and a hindrance to their learning (Comeaux, 2005).

Modern online learning studies offer various applications, including cloud computing as a major technology trend. Frolova (2016) points out that cloud-based learning management system services are gaining popularity and have the capacity to reduce operation costs providing learners with media storage which can be instantly shared by links and found by the keyword.

Gamification, another popular online product nowadays, can also be applied to motivate and engage students better in the process of learning. Lee and Hammer (2011) specify cognitive, emotional and social experiences that gamification proposes players to explore. Bringing game elements teachers can better guide and reward students, show them the ways that education can be a joyful experience, and the blurring of boundaries between informal and formal learning can inspire students to learn in "lifewide", "lifelong", and "lifedeep" ways (Lee \& Hammer, 2011). Investigating the effects of gamification in e-learning on learners' performance, Saran and Al-Magsoosi (2018) presented in their results that students studying with gamification tools have higher grades in comparison with those without the gamification elements.

Massive open online courses (MOOCs) are the latest trend in the field of distance education which seems to go on for some time and indicates a significant need for research studies. Coursera, EdX, Udacity, Udemy, Iversity, MiriadaX and Futurelearn deliver some of the well-known MOOCs platforms around the US and Europe (Baturay, 2015). Kyiv University has already applied such platforms as Moodle, Coursera, and Codecademy to keep abreast of the new emerging challenges.

Against this background, we aimed to conduct a survey to estimate, both qualitatively and quantitatively, feedback on the online Speaking Exam in General English (GE) and pre-exam online learning experience of the first-year students majoring Computer Science and Cybernetics at Taras Shevchenko National University of Kyiv (Ukraine).

The key objective of the study was to investigate the online classes mode during the COVID19 pandemic (March - June 2020) at the University of Kyiv (Ukraine) with a focus on the first-year Computer Science and Cybernetics department students. Particularly, we sought to support the students in developing their GE skills without any break or shock caused by the COVID-19 outbreak. We aimed to provide both L2 learners and teachers with understanding of the situation in Ukraine, its peculiarities and challenges and to equip educators with strategies for the future post-pandemic period.

The study aimed to answer the following research questions:

1. Was the pre-exam online learning effective?

2. Which aspects do online and offline exams differ in and/or are similar to each other?

3. Which issues became mainstream in dealing with influence of online exam distractors on students' academic performance?

\section{Materials and methods}

In order to achieve the objectives of the study, we applied qualitative and quantitative analyses, and descriptive statistics. A voluntary sample group of 60 participants (i.e. four academic groups, 15 students each) was selected. Such a relatively not big number of participants proved to be relevant and statistically significant as the survey was conducted voluntarily under the lockdown reality within the Ukrainian academic settings. All the participants were of the same age (17-18 years old) and the English language level (B1+), majoring in the same field of knowledge (Cybernetics and IT) at Kyiv University. 
This cohort was a homogeneous sample chosen because the students were enrolled in the university with similar admissions criteria, prerequisites, and curricula. Furthermore, as a research instrument 1, a fivequestion online survey was run. The participants reflected on the newly-experienced format of the online Speaking Exam in the summer session (June 2020). This research stage ended up in a qualitative analysis of the collected responses. The data was anonymized and only held for the research time frame - from March to June 2020. Additionally, to interpret students' feedback statistically, quantifiable data was needed. So, we applied a quantitative analysis. As research instruments 2 and 3, we conducted a fivepoint Likert scale ranging and statistical data processing correspondingly. The descriptive statistics was used for outlining the questionnaire response distribution and interpreting students' reflections on a three-month online learning experience. For both qualitative and quantitative approaches, the same sample group of participants was involved.

\section{Participants and setting}

We carried out a case study and obtained students' post-exam feedback through a questionnaire aimed at reconsidering the online exam distractor influence on both students' online exam performance and their mental health. A case was conducting a five-question online survey, and an analysis unit was online questionnaire responses of 60 first-year students of the Computer Science and Cybernetics Faculty at Taras Shevchenko National University of Kyiv (Ukraine) during the Coronavirus lockdown.

We confirm that the research meets the requirements of the ethics committee declared in the "Academic Integrity Code" of Taras Shevchenko National University of Kyiv (http://mobility.univ.kiev.ua/?page_id=1703\&lang=en) and was conducted strictly under the granted ethics approval. The research work provided equal treatment to all students without any force and rights infringement.

\section{Key findings}

\subsection{Online learning approaches at Kyiv University}

The university closure caused by the COVID-19 pandemic has made distance learning a key training option worldwide and particularly in Ukraine.

From the beginning of the lockdown, Taras Shevchenko National University of Kyiv (hereinafter Kyiv University) teachers faced the following major challenges: organizing, running online classes, and checking students' activities. Teaching an online course involved more than replicating classroom strategies in a different form. It required administrative and organizational skills like time management, the ability and willingness to respond to students' questions within 24 hours and provide constructive feedback to students' assignments. Teachers also need to have pedagogical skills to keep students focused on learning, supporting, guiding, and sustaining online presence. The most important technology and social media skills are basic computer skills, proficiency with software applications, installing and updating software and plug-ins, Internet search literacy, grading tools and grade book, tools for synchronous and asynchronous communication, familiarity with platforms for communication and engagement. Technology skills are fundamental here, though social media skills enhance the teacher's ability to connect with students.

Kyiv University's staff reflected accordingly, i.e. teachers monitored and supported students' learning process online. At first, university teachers were trying to have a positive attitude to learning experience online creating a flexible schedule for students and developing some online courses. Teachers and students were communicating via platforms like Viber, Telegram, Skype, Google Duo and Gmail sending the assignments and receiving the feedback. But the very first week of the university closure happened to be a real challenge for both students and staff. Overloading students with excessive tasks online led to loads of email home tasks for teachers to check. In turn, students filled in teachers' emails with so much class and homework that most teachers found themselves mutually exhausted. Later such platforms as Zoom, Coursera, Microsoft Teams, Pear Deck became popular. Teachers developed assignments and tests, scheduled online classes, some of them made their video presentations. Most teachers were assigned to work with the Google Classroom platform where they tested, checked, monitored students' homework, and provided feedback to them. As a result, it soon became clear that remote learning is not just posting numerous assignments in a virtual classroom but implementing diversely relevant technologically generated pedagogy to cover the needs of students.

Adaptation to new reality required online learning technology. The issue of Internet access became crucial. A lot of university teachers experienced problems because of the lack of stable broadband and 
Internet connection, as well as necessary equipment. It was also difficult to explain some topics remotely, not everyone was able to film or edit their own videos. The main idea was not to overload students with online work, but give the essence of the curriculum to keep them interested. We would like to admit that not all the students felt responsible when it came to remote learning. The main task was to organize students for a certain schedule and make it synchronous because the class needed control. The whole idea of students' development and education has been reconceptualized to a new level and educational paradigm. Providing quality education for all in these exceptional times has become a priority.

As a result, we conducted a quick online survey among our students $(n=60)$ and discovered that Zoom and Google Classroom were in top preferable and the most effective in providing live learning. 44 $(73 \%)$ and $31(52 \%)$ respondents supported these platforms correspondingly. 8 students (13\%) claimed to be unable to participate in online learning because of the unstable Internet connection. According to the survey results, asynchronous and synchronous simulation online classes were applied. To reach remote areas, teachers conducted asynchronous e-learning by assigning students with specific articles to read, videos to watch, and a set of related to the topic questions to answer. For the majority with stable access via mobile phone or computer, teachers practiced synchronous learning, i.e. they utilized either social media applications or virtual classrooms to study live. The format involved gathering students into a virtual classroom twice a week according to the faculty timetable. Then, they were given a week off to work on homework assignments, essays, and projects.

\subsection{Reorganization of test control and exam assessment}

In such a challenging situation, assessment practices were also reconsidered. According to the curriculum, students had to pass two Module Tests, Final Test and Speaking Exam within the threemonth quarantine. The teachers were assigned by the university administration not only to deliver online learning they consider the most suitable but also to run test controls up to the point. To evaluate the students' academic progress, the continuous assessment was applied. We utilized Google Forms and designed context-related quizzes and tests. Although the test time was limited, students gave positive feedback on such an assessment format. As soon as the test results revealed the issues the students had difficulty in comprehending, we did our best to make proper adjustments to our online lessons.

At the end of the spring term, we implemented speaking summative assessment to evaluate students' overall learning progress and achievements. To conduct the Speaking Exam in June this year, the Zoom conference room solution was chosen as the most appropriate. Zoom video conferencing tool handles a variety of online communications - real-time messaging and content sharing, team chat, and more, so to keep an eye on students' progress from afar was easy to conduct. We replicated exam control in such a way that each examinee chose his/her exam card through the random number generator service available at https://www.random.org. An exact exam card was shown to each student via the screen share option. The time was specified for each exam part; the total control time of the Speaking Exam was 10 minutes.

Although the examinees had been supported with clear directions for the exam format in advance (in a pre-exam online class), at the exam session some students experienced difficulties online: lingering over the question, misunderstanding, or repeating them and as a result, losing their confidence. Before announcing the final course results a decision to survey the students to receive post-exam feedback was made. The survey contained five qualitative questions aimed at evaluating the students' feedback on the online speaking exam in the summer session in contrast to their previous experience on the offline speaking exam in the winter session of the 2019-2020 academic year:

1. To what extent are online and face-to-face exams different or similar to each other? (1 absolutely different; 5 - completely the same)

2. Did you prepare for the online exam the same you always did for face-to-face exams or somehow differently? (1 - absolutely different; 5 - completely the same)

3. To what extent were you self-controlled and organized at the online exam than a face-toface one? ( 1 - absolutely different; 5 - completely the same)

4. To what level is the online exam more technologically advanced than a traditional one? (1 - absolutely different; 5 - completely the same)

5 . What was the practical value of online learning for your online exam performance? (1 absolutely useless; 5 - very useful).

Regarding Question 1, the respondents estimated the level of online and face-to-face exam similarity/difference from "neutral" (3 points) to "completely the same" (5 points). Most students 
found no difference at all between online and offline speaking exams. For some of them, it was a bit unusual to look at the camera all the time but not into the teacher's eyes.

The level of online and face-to-face exam preparation (Question 2) was also valued from 3 to 5 points. For the majority, the online exam format and tasks were similar to offline ones. It was just an abnormal at-home e-form exam preparation that they considered slightly different.

As for the level of self-control and organization at the online versus face-to-face exam (Question 3 ), it was valued wider - from 2 points ("somehow different") to 5 ("completely the same"). Some students admitted that a comfortable home atmosphere made them more relaxed and less disciplined, whereas the majority claimed that they appeared to be more self-organized because they had to search only for the topic-relevant materials in order to understand them better. A couple of students found themselves as self-organized as always because they consider education as the future whole life success. According to our observations, 17-18 aged freshmen tend to be unstable and inconsistent across some life situations, so it was psychologically predetermined to obtain such varied responses.

In Question 4 the discrepancies in the evaluation of the level of technological advancement of the online versus face-to-face exam were more vivid. Most respondents valued this level in 1-2 points ("absolutely different" and "somehow different" correspondingly). They reflected that despite some success in online learning due to techno provision, traditional offline tests are still more exciting and much less stressful for them. It was a great distractor to experience their hands trembling at the online exam. As the survey student audience was related to the IT field, some respondents valued the level of technological advancement of online examination the highest (5 points) and, as a result, welcomed online controls.

Finally, the responses to Question 5 enabled us to evaluate the practical value of online learning for online exam performance. The majority valued it in 4-5 points ("somehow useful" and "very useful" correspondingly). Some respondents agreed that they benefited from distance learning and, as a result, the online exam because both time and effort were saved. The others claimed that online learning relaxed home surroundings made them stronger and contented and a three-month distance course plus pre-exam meeting contributed much into their online exam performance. Only 8 respondents out of 60 evaluated the practical significance of online learning for online exam performance as "absolutely useless" (1 point) because, as they claimed, online learning made no changes in exam methods, evaluation, and atmosphere.

Then, we interpreted the data on students' online post-exam feedback in the quantitative form (Appendix 1) aimed at conducting a more accurate analysis. Following the Likert scale, the five survey questions were labelled ranging from 1 to 5, where items 1-4 ("Level of online and f2f exam similarity/difference, "Level of online and f2 $\mathrm{f}$ exam preparation", "Level of self-control and organization at online vs $\mathrm{f} 2 \mathrm{f}$ exam", "Level of technological advancement of online vs f2f exam") had the scale points ranked from 1 as "absolutely different" to 5 as "completely the same"; item 5 "Practical value of online learning for online exam performance" was numbered ranging from 1 as "absolutely useless" to 5 - "very useful".

To conduct further analysis of the study, we converted the table numbers into the diagrams using MS Excel and represented them in Figure 1.

The response distribution shown in Figure 1 revealed that $83 \%$ of respondents had estimated the level of online and face-to-face exam similarity/difference (Q1) as the same. As for the ways the students got ready for online and traditional exams (Q2), the majority (90\%) also found no difference at all. The level of self-control and organization at the online exam compared with face-to-face one was estimated as the same by $67 \%(\mathrm{Q} 3)$ and only 2 respondents out of 60 experienced it somehow differently because a comfortable home atmosphere made them more relaxed and less disciplined. Correspondingly, 17\%, $10 \%$, and $30 \%$ of respondents estimated the above-mentioned levels (Q1-3) as neutral, i.e. they did not care much about how to learn and prepare - online or offline. In contrast, these values were completely different in Q4 - where the students were asked to compare the level of technological advancement of online and face-to-face exams. The majority (87\%) estimated this value as different since poor technical provision did not affect their performance at the offline exam; it is the only human interaction between examinee and examiner that matters. On the contrary, at the online Speaking Exam unstable Internet connection, audio, and video breaches caused severe exam anxiety $-10 \%$ of respondents claimed to face a rather unusual condition when their hands started trembling and palms sweating. Eventually, the students' evaluation of the practical value of online learning during the Coronavirus lockdown for their online exam performance was meaningful for our study. A big number of respondents (87\%) estimated 
online learning as useful and beneficial for their exam performance on the whole and for time and effort saving in particular, and they proved it at the online Speaking Exam (see Table 1).

Q1 "Level of online and f2f exam similarity/difference"

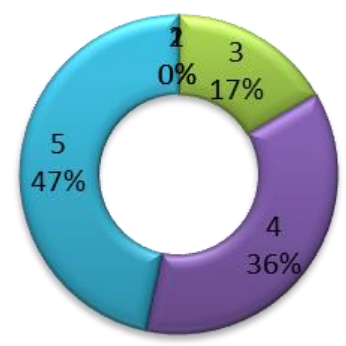

Q2 "Level of online and f2f exam preparation"

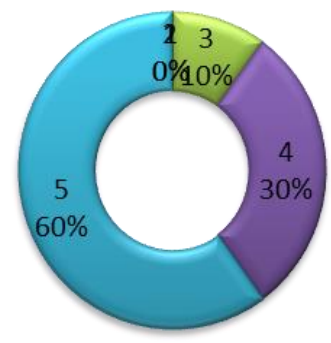

Q3 "Level of self-control at online vs f2f exam"

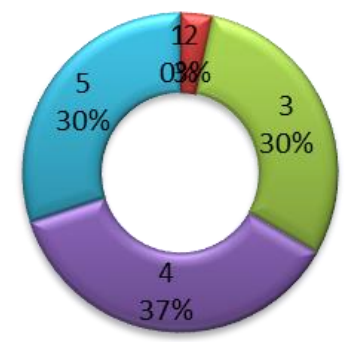

Q4 "Level of technological advancement of online vs f2f exam"

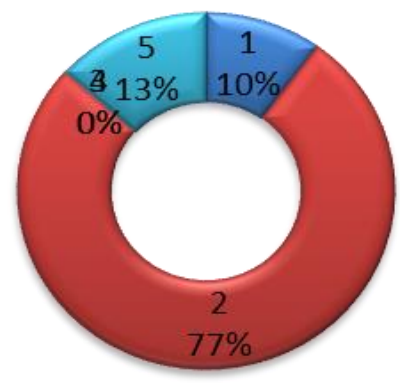

Q5 "Practical value of online learning for online exam performance"

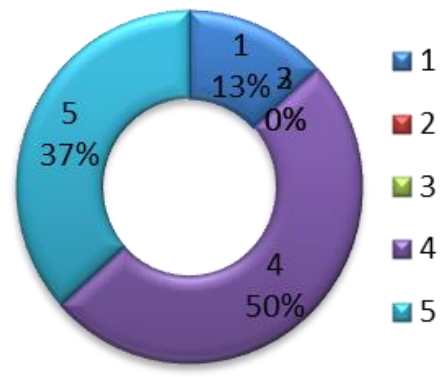

Fig. 1 The response distribution on the online exam survey questions

(Q1-4: 1 -absolutely different; 5 - completely the same; Q5: 1-absolutely useless; 5 - very useful)

Table 1. Students' academic performance results at off- and online EL exams in 2019-20 AY

\begin{tabular}{lcccc}
\hline & \multicolumn{3}{c}{$\begin{array}{c}\text { Students' } \\
\end{array}$} & $\begin{array}{c}\text { Academic Performance Assessment Scale } \\
\text { (Leigh \& Yvonne, 2017, p.142) }\end{array}$ \\
\cline { 2 - 5 } & $\begin{array}{c}90-100 \\
\text { "Excellent" }\end{array}$ & $\begin{array}{c}75-89 \\
\text { "Fairly good" }\end{array}$ & $\begin{array}{c}60-74 \\
\text { "Pass" }\end{array}$ & $\begin{array}{c}\text { below 60 } \\
\text { "Fail" }\end{array}$ \\
\hline $\begin{array}{l}\text { Offline exam } \\
\text { (Winter 2019 Session) }\end{array}$ & $\begin{array}{c}40 \text { students } \\
67 \%\end{array}$ & $\begin{array}{c}20 \text { students } \\
33 \%\end{array}$ & 0 students & 0 students \\
\hline $\begin{array}{l}\text { Online exam } \\
\text { (Summer 2020 Session) }\end{array}$ & $\begin{array}{c}32 \text { students } \\
53 \%\end{array}$ & $\begin{array}{c}24 \text { students } \\
40 \%\end{array}$ & $\begin{array}{c}4 \text { students } \\
7 \%\end{array}$ & 0 students \\
\hline
\end{tabular}

As shown in Table 1, the summer 2020 online exam outcomes are slightly worse than those of the offline winter exam. If in the winter 2019 session no examinees received less than 75 points, this time 4 students worsened their performance. At the online exam, the four students performed with uncertainty, they were prone to self-control failure and did not produce easy-to-follow speech. $40 \%$ of online examinees also suffered from some failures, particularly, a technical support break. Nevertheless, it did not interfere much with their exam results. The rest 53\% of examinees seemed at ease with themselves and either time pressure or the Internet access breaches did not distract them. They applied the acquired knowledge fully.

The conducted survey enabled us to reconsider the online exam distractor influence not only on students' performance but also on their mental health. It was a new experience for us to apply moral assessment principles. Hereby, the ethical aspect became mainstream. 


\subsection{Ethical behavior of both students and teaching staff}

As mentioned above, not all students had Internet access and, on the other hand, not all teachers appeared to be technologically skillful enough to generate productive online learning. Some teachers, for instance, took Cambridge English language online course to improve their skills working online.

Not less importantly, teachers were urged to handle emerging social and health issues: not to overload the students with excessive assignments, prevent them from long-hour staring at screens, reduce the increased level of stress, implement measures to ensure that students including those with disabilities or from low-income backgrounds have access to distance learning programs.

Online teaching is a good solution when educational equality is observed. Of course, full equality may not be possible as technological conditions vary too much from student to student, but all possible efforts to promote equal treatment were made. Those with poor Internet connections were given writing assignments by mail. Google Duo's stable application helped to provide connections in distant rural areas. The factual dialogue was created with each student improving his/her knowledge, skills, and abilities.

Homeworking, self-isolation and online communication show that social, emotional, and mental strengths are as necessary as intellectual capacity. Understanding students' needs in time of pandemics has become another priority for teachers. Responding to students' questions within a couple of hours and even quicker provide integrity and reliability to the online work.

Subsequently, another question has been actualized "Is online learning more conducive to cheating?" Proactively preventing cheating and plagiarizing are the key factors in online education. Encouraging students to express their thoughts and opinions freely, reading more literature on the subject, and giving feedback can contribute to a fruitful dialogue between the teacher and the student as well as develop their soft skills. Giving explanations to their students how cheating interferes with their opportunities to learn and develop academically is a necessary part of online learning.

Some rules and regulations have been applied to online testing. Some tasks and assignments were done in a written form via email to sum up the material taken so that students could get ready for more complicated tests online. Google classroom allowed creating and having time-set assignments where cheating is minimized.

Consequently, the teacher has to exert every effort to raise professional standards, improve service, promote an environment where personal integrity, dignity, and mutual respect are practiced and eagerly implemented. After all, the biggest priority has been keeping students safe and contented.

\subsection{Technology adaptation of Kyiv University}

The concept of KNU online education was first introduced on the $1^{\text {st }}$ of February 2018. The project aimed at developing video courses on YouTube channel to help students with online courses. Such platforms as Ted ED, Coursera, and Codecademy inspired the administration to create its own educational platform. Previously used Moodle remote education platform could not satisfy the needs of online university learning and in March 2020 Students Parliament offered access to Coursera for Campus platform which was on the Ministry of Education list of platforms. Students got access to 3800 courses of 400 specialties. That contributed to online education and helped students to finish courses on different subjects.

In post-pandemic reality, the need for a digital university remained the priority. The $K N U$ Education Online digital platform (https:/view.genial.ly/5ecb71829330ad0d7cd6f2e5/presentationcifrovij-universitet) as a part of the Digital University. University in a Smartphone project (http://www.univ.kiev.ua/en/news/11090) was introduced on the $3^{\text {rd }}$ of January 2020 and is going to be fully used in September 2020. It all started just as a student and teacher online classroom design, but the Coronavirus spreading pushed the distance learning online platform development. There are some useful features there. Teacher's room enables the user to place all necessary materials: lectures, presentations, assignments, tests for lab and classroom activities, cases, e-literature, videos. Also, a teacher has access to the interactive timetable, communicates with students and administration. Student's room allows using all the tools necessary for online learning. Students can watch interactive lectures, videos, take tests, hand in different assignments: lab works, cases, term papers, diplomas, etc. They have online access to interactive timetable, teachers, and administration. Digital library is supposed to store all possible eliterature embedded in online lectures and assignments. Online presentation aims at using all the modern tools to demonstrate the material, online video courses. The idea of testing online allows carrying out the assignments from quizzes to exam tests. Interactive timetable gives information to all classes and $e$ - 
register guarantees continuous assessment in private teacher's room. The administration has access to the processed information of students' academic success.

Currently, the KNU Education Online platform is being tested at the Faculties of Economics and Law. It has enabled 6,300 users to work with and explore online learning opportunities. The program presupposes that a user can utilize the mobile application for both Android and iOS. Thus, the university has received a full platform for distance learning. The COVID-19 pandemic and school closure have pushed the process of inevitable changes in the educational process in Ukraine - a traditional university setting is about to be enlarged with online learning tools and services.

6. Conclusions. Suspension of in-person classes from March 12, 2020, at Kyiv University resulted not only in transitioning lessons but first of all, in reconsidering both teachers' and students' attitudes to class delivery and examinations conduct. In the face of adversity, our university staff did not miss the chance to try something new. We approached techno-based experiences and utilized the relevant to the subject learning tools that met students' expectations and fit for purpose.

In Research Question 1, we targeted to identify effectiveness of online learning format. We found out that the students benefited the most from synchronous simulation assignments. Taking advantage of Google Forms, Google Classroom, and Zoom online tools, we managed to ensure that students receive a quality education. Live online learning contributed much both to the students' grades and self-confidence at the summer Speaking Exam. Time and effort saving contributed into their online exam performance as well. Following Research Question 2, we interviewed 60 participants aimed at comparing online versus offline exam modes. In such aspect as the exam preparation procedure, the students found no difference at all, while other aspects (self-control level and technological advancement) appeared to be varied. Searching for the topic relevant materials for better understanding in a cosy at-home environment boosted some participants' self-organisation and control, while others, on the contrary, evaluated themselves much less disciplined. All of the participant agreed on completely different level of online and offline exams technical advancement. Some of them suffered from poor Internet connection, while others welcomed online controls. The investigation of Research Question 3 showed that an ethical aspect became mainstream. We reconsidered the online exam distractors influence and experienced moral assessment principles application. To generate productive online learning, we did not overload the students with excessive assignments, preventing their long-hour screen staring, instead, we engaged them in as many interactive activities provided by online educational platforms and technical tools as possible. Consequently, the situation urged the Kyiv University administration to develop the university-wide online learning platform in order to apply education equality.

Regardless of broadband Internet access inequities generated by online learning, it is a combination of diverse training techniques relevant on purpose with the appropriate ethical policy which made remote learning in Kyiv University successful. Being devastating in the eye of the whole mankind, the COVID-19 pandemic appeared to be "fruitful" in terms of education, as it pushed forward the processes on the prospective and long-run technological enhancement of education, generated the necessity of teachers' skill further development, as well as triggered reconsideration and reshaping ethical policies both at the university level and globally.

7. Limitations. Although we processed and analyzed the survey responses on the online Speaking Exam of the Kyiv University's students, the obtained outcomes are reliable and relevant not only inside the Ukrainian academic setting but also could be applied as an option in other higher education institutions. It is necessary to mention that the format of online exams is to be developed and reorganized to avoid students' cheating and make the process more flexible and innovative. Despite the fact that a relatively small participants' number was used to collect data, the results and key findings present significant further research on online learning in times of lockdowns and social distancing due to the COVID-19 pandemic. Our findings may assist educators in providing measures and strategies to address the consequences of the pandemic, conducting the online evaluation of students' achievements, and reinventing new distance learning environments to ensure continuity and high-quality education. 


\section{REFERENCES}

1. Arend, B. D. (2007). Course Assessment Practices and Student Learning Strategies in Online Courses. Journal for Asynchronous Learning Networks, 11(4), 3-13.

2. Atlantis Group Report (2020, April 29). COVID-19 Represents Most Significant Challenge to Education Since WW2. https://www.varkeyfoundation.org/opinion/covid-19-represents-most-significant-challenge-toeducation-since-ww2.

3. Baturay, M. H. (2015). An overview of the world of MOOCs. Procedia - Social and Behavioral Sciences, 174, 427-433.

4. Blaschke L. M. \& Bedenlier, S. (2020, April). Online Learning. Oxford Research Encyclopedia of Education. doi:10.1093/acrefore/9780190264093.013.674.

5. Comeaux, P. (2005-2006). Assessing Students' Online Learning: Strategies and Resources. Essays on Teaching Excellence Toward the Best in the Academy, 17(3). https://cft.vanderbilt.edu/wpcontent/uploads/sites/59/vol17no3_assessing_online_learning.html.

6. Ebner, N., \& Press, S. (2020, March 19). Pandemic Pedagogy II: Conducting Simulations and Role Plays in Online, Video-Based, Synchronous Courses. SSRN. doi:10.2139/ssrn.3557303.

7. Ebner, N. (2020, March 10). "Next Week, You Will Teach Your Courses Online": A Reassuring Introduction to Pandemic Pedagogy. SSRN. https://ssrn.com/abstract=3552124.

8. Frolova, N. H. (2016). E-learning: Trends and Stepping Stones. Historical and Social Educational Ideas, 8(5/2), 186-189. doi:10.17748/2075-9908-2016-8-5/2-186-189.

9. Houlden, S., \& Veletsianos, G. (2020, March 13). COVID-19 Is Pushing Universities to Switch to Online Classes - But Are They Ready? Phys.org. https://phys.org/news/2020-03-covid-universities-onlineclassesbut-ready.html.

10. Kentnor, H. E. (2015). Distance Education and the Evolution of Online Learning in the United States. Curriculum and Teaching Dialogue, 17(1-2), 21-34.

11. Leigh, N. W., \& Yvonne, A. B. (2017). Success in Higher Education: Transitions to, within and from University. Springer Nature Singapore Ltd. doi:10.1007/978-981-10-2791-8.

12. Liu, J. C. (2019). Evaluating Online Learning Orientation Design with a Readiness Scale. Online Learning, 23(4), 42-61. doi:10.24059/olj.v23i4.2078.

13. Martin, F., Stamper, B., \& Flowers, C. (2020). Examining Student Perception of Their Readiness for Online Learning: Importance and Confidence. Online Learning, 24(2), 38-58. doi.org/10.24059/olj.v24i2.2053.

14. Muller, K., Scalzo, K. A., Pickett, A. M., Dubuc, L., Dugan, L., McCabe, R., Pelz, W., \& Simiele, D. (2020). Ensuring Online Learning Quality: Perspectives from the State University of New York. Online Learning, 24(2), 254-268. doi.org/10.24059/olj.v24i2.2004.

15. Picciano, A. G., Seaman, J., \& Allen I. E. (2010). Educational Transformation Through Online Learning: To Be Or Not To Be. Journal of Asynchronous Learning Networks, 14(4). doi:10.24059/olj.v14i4.147.

16. Rebenko, M., Nikolenko, N., \& Rebenko, V. (2019). Listening Comprehension Proficiency Development of Information Technology Students in ESP classroom. International Journal of Learning, Teaching and Educational Research, 18(11), 245-264. doi:10.26803/ijlter.18.11.15.

17. Robinson, H. A., Kilgore, W. \& Warren, S. J. (2017). Care, Communication, Learner Support: Designing meaningful online collaborative learning. Online Learning, 21(4), 29-51. doi:10.24059/olj.v21i4.1240.

18. Sahu, P. (2020, April 04). Closure of Universities Due to Coronavirus Disease 2019 (COVID-19): Impact on Education and Mental Health of Students and Academic Staff. Cureus, 12(4). doi:10.7759/cureus.7541.

19. Sandu, A. (2020, May 20). Pandemic - Catalyst of the Virtualization of the Social Space. Postmodern Openings, 11(1Supl2), 115-140. doi:10.18662/po/11.1sup2/146.

20. Saran, M. \& Al-Magsoosi, D. (2018). Gamification in E-Learning: The Effect on Student Performance. 9th Annual International Conference on Computer Science Education: Innovation and Technology (CSEIT). Singapore. https://www.researchgate.net/publication/329415817_Gamification_in_elearning_The_Effect_on_Student_Performance.

21. Scagnoli, N. I., Buki, L. P. \& Johnson, S. D. (2009). The Influence of Online Teaching of Face-to-face Teaching Practices. Journal of Asynchronous Learning Networks, 13(2). https://www.researchgate.net/publication/287013482_The_influence_of_online_teaching_on_face-toface_teaching_practices.

22. Shenoy, V., Mahendra, S., \& Vijay, N. (2020, April). COVID 19 Lockdown Technology Adaption, Teaching, Learning, Students Engagement and Faculty Experience. Mukt Shabd Journal, 9(4), 698-702. https://www.researchgate.net/publication/340609688.

23. Stark, E. (2019). Examining the Role of Motivation and Learning Strategies in Student Success in Online Versus Face-to-face Courses. Online Learning, 23(3), 234-251. doi:10.24059/olj.v23i3.1556. 


\section{Appendix 1}

Data on students' online post-exam feedback interpreted in the quantitative form

\begin{tabular}{|c|c|c|c|c|c|}
\hline & $\mathrm{Q} 1$ & $\mathrm{Q} 2$ & Q3 & $\mathrm{Q} 4$ & Q5 \\
\hline Expert & $\begin{array}{l}\text { Level of online and } \\
\text { f } 2 \mathrm{f} \text { exam } \\
\text { similarity/difference }\end{array}$ & $\begin{array}{l}\text { Level of online } \\
\text { and f } 2 \mathrm{f} \text { exam } \\
\text { preparation }\end{array}$ & $\begin{array}{l}\text { Level of self- } \\
\text { control and } \\
\text { organization at } \\
\text { online vs f } 2 \mathrm{f} \\
\text { exam } \\
\end{array}$ & $\begin{array}{c}\text { Level of } \\
\text { technological } \\
\text { advancement of } \\
\text { online vs f2f } \\
\text { exam }\end{array}$ & $\begin{array}{c}\text { Practical value } \\
\text { of online } \\
\text { learning for } \\
\text { online exam } \\
\text { performance }\end{array}$ \\
\hline 1. & 5 & 5 & 5 & 2 & 5 \\
\hline 2. & 5 & 4 & 4 & 2 & 4 \\
\hline 3. & 5 & 5 & 4 & 2 & 4 \\
\hline 4. & 5 & 4 & 4 & 1 & 4 \\
\hline 5. & 4 & 3 & 3 & 2 & 4 \\
\hline 6. & 4 & 4 & 4 & 2 & 4 \\
\hline 7. & 4 & 4 & 4 & 2 & 4 \\
\hline 8. & 4 & 3 & 5 & 2 & 1 \\
\hline 9. & 3 & 4 & 3 & 2 & 4 \\
\hline 10. & 5 & 5 & 3 & 2 & 4 \\
\hline 11. & 3 & 5 & 3 & 1 & 1 \\
\hline 12. & 3 & 5 & 2 & 2 & 1 \\
\hline 13. & 5 & 5 & 5 & 2 & 5 \\
\hline 14. & 3 & 3 & 4 & 2 & 4 \\
\hline 15. & 3 & 5 & 3 & 5 & 5 \\
\hline 16. & 5 & 5 & 4 & 2 & 5 \\
\hline 17. & 5 & 5 & 3 & 2 & 4 \\
\hline 18. & 4 & 5 & 3 & 2 & 5 \\
\hline 19. & 5 & 5 & 5 & 2 & 4 \\
\hline 20. & 4 & 4 & 4 & 2 & 5 \\
\hline 21. & 5 & 5 & 5 & 2 & 5 \\
\hline 22. & 4 & 4 & 3 & 5 & 1 \\
\hline 23. & 5 & 5 & 5 & 5 & 5 \\
\hline 24. & 5 & 5 & 5 & 2 & 4 \\
\hline 25. & 4 & 4 & 4 & 1 & 4 \\
\hline 26. & 5 & 5 & 5 & 5 & 4 \\
\hline 27. & 4 & 5 & 4 & 2 & 5 \\
\hline 28. & 5 & 5 & 5 & 2 & 5 \\
\hline 29. & 4 & 4 & 4 & 2 & 4 \\
\hline \multirow[t]{2}{*}{30.} & 4 & 5 & 3 & 2 & 5 \\
\hline & $\begin{array}{l}1 \text { - absolutely } \\
\text { different; } 5- \\
\text { completely the } \\
\text { same }\end{array}$ & $\begin{array}{c}1 \text { - absolutely } \\
\text { different; } 5- \\
\text { completely the } \\
\text { same }\end{array}$ & $\begin{array}{c}1 \text { - absolutely } \\
\text { different; } 5- \\
\text { completely the } \\
\text { same }\end{array}$ & $\begin{array}{l}1 \text { - absolutely } \\
\text { different; } 5- \\
\text { completely the } \\
\text { same }\end{array}$ & $\begin{array}{c}1 \text { - absolutely } \\
\text { useless; } 5 \text { - very } \\
\text { useful }\end{array}$ \\
\hline
\end{tabular}

